Arthur E. Schwartz MD, Farrokh R. Maneksha MD, W. Walter Backus MD, Marc S. Kanchuger MD, William L. Young MD

\title{
Nimodipine decreases the minimum alveolar concentration of iso- flurane in dogs
}

Nimodipine is a calcium antagonist that binds with high affinity to neuronal membranes. It is a potent cerebrovasodilator and has been demonstrated also to affect neurotransmitter symthesis and release. Because patients undergoing surgery for intracranial aneurysms are frequently receiving nimodipine, the authors determined the MAC of isoflurane in six dogs before and during three infusion doses of nimodipine $10.5,1.0$ and $2.0 \mu \mathrm{g}$. $\left.\mathrm{kg}^{-1} \cdot \mathrm{min}^{-1}\right)$, MAC was also determined in five dogs before and during infusion of the drug vehicle $\left(10 \mu \mathrm{l} \cdot \mathrm{kg}^{-1} \cdot \mathrm{min}^{-1}\right)$. Nimodipine produced a reduction in MAC from $1.47 \pm 0.33 \% 10$ $1.19 \pm 0.18,1.15 \pm 0.18$ and $1.15 \pm 0.09 \%$ during infusions of nimodipine $0.5,1.0$ and $2.0 \mu \mathrm{g} \cdot \mathrm{kg}^{-1} \cdot \mathrm{min}^{-1}$, respectively $(P<0.05)$. Infusion of drug vehicle alone produced no change in $M A C(1.39 \pm 0.15 \%)$. This reduction in anaesthetic requirement by nimodipine may be due to its effect on neurotransmission. Adjustments in anaesthetic dosage may be necessary in patients receiving nimodipine

La nimodipine est un bloqueur des canaux calciques relativement spécifique aux cellules nerveuses. C'est un vasodilatateur cérébral puissant qui modifie aussi la synthèse et la libération des neurotransmetteurs. Comme elle est populaire chez les candidats d̀ une chirurgie pour anévrysme cérébral, nous avons d'abord mesuré le MAC de l' isoflurane chez six chiens avant et pendant la perfusion de trois doses de nimodipine $(0,5,1,0$ et

\section{Key words}

ANAESTHETICS, VOLATILE: isoflurane;

IONS: calcium;

PHARMACOLOGY: nimodipine;

POTENCY, ANAESTHETIC: MAC.

From the Department of Anesthesiology, College of Physicians and Surgeons, Columbia University; and Department of Anesthesiology, State University of New York, Stony Brook, N.Y.

Address correspondence to: Dr. Arthur E. Schwartz, Neuroanesthesia Group, AP 9 North, Department of Anesthesiology, College of Physicians and Surgeons of Columbia University, 16I Fort Washington Avenue, New York, NY 10032.

Accepted for publication 17th October 1990.
2,0 $\left.\mu \mathrm{g} \cdot \mathrm{kg}^{-1} \cdot \min ^{-1}\right)$. Chez cing chiens, nows avons aussi mesuré l'effet de la perfusion du véhicule de la nimodipine $a$ raison de $10 \mu \mathrm{l} \cdot \mathrm{kg}^{-1} \cdot \mathrm{min}^{-1}$ sur le $M A C$. Avec $0,5,1,0$ et 2,0 $\mu \mathrm{g} \cdot \mathrm{kg}^{-1} \cdot \mathrm{min}^{-1}$ de nimodipine, le MAC de l' isoflurane passait de $1,47 \pm 0,33 \%$ a $1,19 \pm 0,18,1,15 \pm 0,18$ et $1,15 \pm 0,09 \%$ respectivement. Employé seul, le véhicule de la nimodipine ne modifiait pas le MAC de l'isoflurane $(1,39 \pm 0,15 \%)$. Cette diminution des besoins en anesthésique résulte peut-être des effets de la nimodipine sur la transmission nerveuse et il faudra sans doute en tenir compte en pratique.

Acute administration of calcium channel antagonists alters the effects of a variety of anaesthetic agents. ' Verapamil, nitrendipine and flunarizine have all been reported to augment the anaesthetic potencies of ethanol, pentobarbital and argon in mice. Nitrendipine has been shown to alter nitrous oxide anaesthesia, tolerance and dependence. ${ }^{2}$ Furthermore verapamil reduced the minimum alveolar concentration of halothane in dogs. ${ }^{3}$

Nimodipine is a calcium channel antagonist with high affinity binding sites which are in close proximity to, or part of, membrane calcium channels. ${ }^{4}$ It has recently gained popularity for the treatment of vasospasm associated with subarachnoid haemorrhage. ${ }^{5}$ Furthermore, nimodipine has been shown to improve neurologic outcome following complete cerebral ischaemia in primates. ${ }^{6}$ Since nimodipine is frequently administered to patients undergoing anaesthesia and surgery for intracranial aneurysms, this study was designed to determine if nimodipine alters the anaesthetic effect of isoflurane in dogs.

\section{Methods}

This study was approved by the Institutional Committee on Research Involving Animal Subjects. General anaesthesia was induced by inhalation of isoflurane $2-3 \%$ and oxygen via mask in 11 mongrel dogs of either sex, weighing $15-19 \mathrm{~kg}$. Tracheal intubation was accomplished with a cuffed $8.0 \mathrm{~mm}$ endo-tracheal tube without the use of muscle relaxants. The dogs' lungs were then ventilated at a rate of ten breaths per minute. The tidal 
volume was adjusted to achieve an end-tidal carbon dioxide tension between 28 and $38 \mathrm{mmHg}$, as measured by infrared analysis (Siemens). Catheters were inserted into a femoral vein and artery and a continuous iv infusion of lactated Ringer's solution was begun at the rate of 4 $\mathrm{ml} \cdot \mathrm{kg}^{-1} \cdot \mathrm{hr}^{-1}$. A heating pad was used to keep nasal temperature at $37.0 \pm 0.5^{\circ} \mathrm{C}$. Temperature, ECG, arterial blood pressure and end-tidal carbon dioxide tension were continuously recorded. Isoflurane concentration was measured by infrared analysis with a Puritan Bennet Anesthetic Agent Monitor 222 (Wilmington, MA) The analyzer was calibrated for each study to the known concentration of calibration gas supplied by the manufacturer and to $0 \%$. The instrument has a sensitivity of $0.1 \%$ and a maximum rise time of $600 \mathrm{msec}$. Exhaled gas was obtained from a $5 \frac{1}{4}$ inch 16-gauge Teflon catheter inserted through the endotracheal tube.

The MAC of isoflurane necessary to prevent purposeful movement in response to tail clamping was determined according to the method previously reported. ${ }^{7}$ The base of the tail was shaved. After a stable end-tidal isoflurane concentration was maintained for at least $15 \mathrm{~min}$, a clamp was applied to the base of the tail and closed to full ratchet lock for one minute or until purposeful movement was elicited. Following the determination of the response to the tail-clamp, the end-tidal isoflurane concentration was adjusted either up or down as appropriate, and response to tail-clamp was again determined. Purposeful movement was defined as gross movement of the head or extremities and did not include coughing, chewing, swallowing, or increased respiratory effort. The MAC was determined to be midway between the stable end-tidal concentrations of isoflurane (to the nearest 0.1 volume per cent) at which the animal did or did not move in response to the stimulus. Multiple tail-clamps were applied at multiple concentrations in each animal to determine MAC to the nearest $0.1 \%$.

Following determination of the control MAC for isoflurane, six dogs received a continuous iv infusion of nimodipine at a rate of $0.5 \mu \mathrm{g} \cdot \mathrm{kg}^{-1} \cdot \mathrm{min}^{-1}$. After $30 \mathrm{~min}$ of infusion MAC was again determined by the same technique. The MAC determinations were repeated after 30 min of nimodipine infusion given at an increased rate of $1.0 \mu \mathrm{g} \cdot \mathrm{kg}^{-1} \cdot \mathrm{min}^{-1}$ and finally after $30 \mathrm{~min}$ of 2.0 $\mu \mathrm{g} \cdot \mathrm{kg}^{-1} \cdot \mathrm{min}^{-1}$ infusion.

Five dogs received the drug vehicle alone, infused at a rate of $10 \mu \mathrm{l} \cdot \mathrm{kg}^{-1} \cdot \mathrm{min}^{-1}$, which equals the volume of vehicle that was infused at the maximum nimodipine dose $\left(2.0 \mu \mathrm{g} \cdot \mathrm{kg}^{-1} \cdot \mathrm{min}^{-1}\right)$. After $30 \mathrm{~min}$ of vehicle infusion, MAC was again determined by the same method.

Both drug vehicle and nimodipine were provided by Miles Inc. (West Haven, CT). Solutions were diluted in $5 \%$ dextose solution prior to infusion.
TABLE I MAC of isoflurane before and after nimodipine $(n=6)$ (mean $\pm \mathrm{SD}$ )

\begin{tabular}{ll}
\hline & MAC (volume per cent) \\
\hline Prior to nimodipine & $1.47 \pm 0.32^{*}$ \\
Nimodipine $\left(0.5 \mu \mathrm{g} \cdot \mathrm{kg}^{-1} \cdot \mathrm{min}^{-1}\right)$ & $1.19 \pm 0.18$ \\
Nimodipine $\left(1.0 \mu \mathrm{g} \cdot \mathrm{kg}^{-1} \cdot \mathrm{min}^{-1}\right)$ & $1.15 \pm 0.18$ \\
Nimodipine $\left(2.0 \mu \mathrm{g} \cdot \mathrm{kg}^{-1} \cdot \mathrm{min}^{-1}\right)$ & $1.15 \pm 0.09$ \\
\hline
\end{tabular}

* $P<0.05$ compared with MAC after nimodipine.

Control values for MAC and mean arterial pressure (MAP), obtained before infusion of nimodipine, and at each drug infusion rate were compared by repeated measures one-way analysis of variance. Values for MAC and MAP before and after infusion of drug vehicle were compared by paired t test. $P<0.05$ was considered statistically significant.

\section{Results}

As shown in Table 1, the MAC of isoflurane decreased following the administration of nimodipine. There were no significant differences in the magnitude of MAC reduction among the three doses of drug. The mean reduction in MAC was $19.5 \%$ of the control value. Administration of drug vehicle, alone, resulted in no change in isoflurane MAC (Table II). There were no differences in mean arterial pressure measured after each MAC determination (Table $\mathrm{WI}$ ).

\section{Discussion}

The neuronal effects of calcium antagonists appear to be mediated through slowly inactivating calcium ion channels (L-type) whose blockade leads to reduced intracellular entry of $\mathrm{Ca}^{++8}$ Both neuronal and cerebrovasodilatory effects have been identified at nimodipine doses that produce no effect on peripheral circulation. ${ }^{9-11}$ Nimodipine at $0.1-10 \mu \mathrm{M}$ concentrations has been shown to inhibit the release of radiolabelled acetylcholine from rat striatal and cerebral cortical slices. ${ }^{12}$ In the same preparation dopamine release was enhanced. However, in vivo, Pileblad and Carlsson reported that, in mice, nimodipine produced a dose-dependent decrease in the synthesis of brain dopamine and norepinephrine. ${ }^{13,14}$ Furthermore, nimodipine has also been shown to reduce the evoked release of norepinephrine in cultured rat neurons. ${ }^{15}$ In the guinea pig ileum muscle strip preparation, $\alpha_{2-}$ adrenoceptor blocking agents failed to enhance norepinephrine release in the presence of nimodipine. This suggests an $\alpha_{2}$-adrenoceptor blocking property of nimodipine. ${ }^{16}$

The effect of nimodipine on endogenous opioids may 
TABLE II MAC of isoflurane before and after drug vehicle $(n=5)$ (mean $\pm \mathrm{SD}$ )

MAC (volume per cenu)

\begin{tabular}{ll}
\hline Prior to drug vehicle & $1.39 \pm 0.15$ \\
After drug vehicle $\left(10 \mu \mathrm{l} \cdot \mathrm{kg}^{-1} \cdot \mathrm{min}^{-1}\right)$ & $1.39 \pm 0.15$ \\
\hline
\end{tabular}

TABLE III Mean arterial blood pressure (MAP) at MAC determinations (mean $\pm S D$ )

\begin{tabular}{ll}
\hline & MAP $(\mathrm{mmHg})$ \\
\hline $\begin{array}{l}\text { Nimodipine group }(n=6) \\
\text { Prior to nimodipine }\end{array}$ & $104.2 \pm 15.7$ \\
Nimodipine $\left(0.5 \mu \mathrm{g} \cdot \mathrm{kg}^{-1} \cdot \mathrm{min}^{-1}\right)$ & $102.7 \pm 13.5$ \\
Nimodipine $\left(1.0 \mu \mathrm{g} \cdot \mathrm{kg}^{-1} \cdot \mathrm{min}^{-1}\right)$ & $103.2 \pm 12.6$ \\
Nimodipine $\left(2.0 \mu \mathrm{g} \cdot \mathrm{kg}^{-1} \cdot \mathrm{min}^{-1}\right)$ & $102.3 \pm 12.6$ \\
& \\
Drug vehicle group $(11=5)$ & $95.0 \pm 8.7$ \\
Prior to drug vehicle & $97.0 \pm 10.5$ \\
Drug vehicle $\left(10 \mu \mathrm{l} \cdot \mathrm{kg}^{-1} \cdot \mathrm{min}^{-1}\right)$ & \\
\hline
\end{tabular}

explain the reduction in anaesthetic requirement. Costa $e t$ al. demonstrated that iv nimodipine $(1,10$ and 100 $\mu \mathrm{g} \cdot \mathrm{kg}^{-1}$ ) raised plasma $\beta$-endorphin levels but reduced pituitary concentrations. This suggests that nimodipine may increase $\beta$-endorphin release from the pituitary. ${ }^{17}$

The doses of nimodipine were chosen to be within the range administered clinically for the treatment of vasospasm following subarachnoid haemorrhage in man. ${ }^{18}$ These doses have also been shown to improve neurological outcome following cerebral ischaemia in animals. ${ }^{6}$ The lack of a discrete dose-response relationship in the reduction of anaesthetic requirement by nimodipine probably reflects the relative insensitivity of MAC measurement in discriminating small changes in anaesthetic potency. This may also indicate a nonspecific, nonreceptor-mediated action of nimodipine on anaesthesia. Smaller doses of nimodipine would have been subclinical with expected reductions in MAC near the limit of sensitivity of this laboratory technique. ${ }^{18}$ The absence of significant haemodynamic changes at these doses of calcium antagonist is in agreement with previous reports. ${ }^{6,10}$

The finding that nimodipine reduces the MAC of isoflurane is in agreement with previous evidence of an interaction between calcium channel antagonists and anaesthetic agents. This effect would be particularly important in patients suffering from vasospasm undergoing intracranial aneurysm surgery, for whom anaesthetic dose must be carefully titrated to allow rapid emergence and timely evaluation of neurological function. The mechanism, however, by which inhibition of the influx of extracellular calcium may augment the action of anaesthetics remains to be clarified.

\section{References}

I Dolin SJ, Litlle HJ. Augmentation by calcium channel antagonists of general anaesthetic potency in mice. $\mathrm{Br} J$ Pharmacol 1986; 88: 909-14.

2 Dolin SJ, Little HJ. Effects of nitrendipine on nitrous oxide anesthesia, tolerance and physical dependence. Anesthesiology 1989; 70: 91-7.

3 Maze M, Mason DM, Kates RE. Verapamil decreases MAC for halothane in dogs. Anesthesiology 1983; 59: 327-9.

4 Glossman H, Ferry DR, Goll A, Striessnig J, Schober $M$. Calcium channels: basic properties as revealed by radioligand binding studies. J Cardiovasc Pharmacol 1985; 7: 520-30.

5 Petruk KC, West $M$, Molir et al. Nimodipine treatment in poor-grade aneurysm patients: Results of a multicenter double-blind placebo-controlled trial. J Neurosurg 1988; 68: 505-17.

6 Steen PA, Gisvold SE, Milde JH et al. Nimodipine improves outcome when given after complete cerebral ischemia in primates. Anesthesiology 1985; 62: 406-14.

7 Schwartz AE, Maneksha FR, Kanchugar MS, Sidhu US, Poppers $P J$. Flumazenil decreases the minimum alveolar concentration of isoflurane in dogs. Anesthesiology 1989; 70: 764-6.

8 Scriabine A, Schuurman T, Traber J. Pharmacological basis for the use of nimodipine in central nervous system disorders. FASEB 1989; 3: 1799-806.

9 Kazda S,Garthoff B, Krause HP, Schlossmann K. Cerebrovascular effects of the calcium antagonistic dihydropyridine derivative, nimodipine, in animal experiments. Arzneimittelforschung 1982; 32: 331-8.

10. Kazda $S$, Garthoff B, Luckhow G. Ca antagonists prevent brain damage in stroke-prone spontaneously hypertensive rats independent of their effect on blood pressure: Nimodipine vs. nitrendipine. J Cereb Blood Flow Metab 1983; 3: 526-7.

11 Hoffmeister F, Benz V, Heise A, Krause HP, Neuser $V$. Behavioral effects of nimodipine in animals. Arzneimittelforschung $1982 ; 32: 347-60$.

12 Nordström O, Braesch-Andersen S, Bartfai T. Dopamine release is enhanced while acetylcholine release is inhibited by nimodipine (BAY E9736). Acta Physiol Scand 1986; 126: 115-9.

13 Pileblad E, Carlsson A. The $\mathrm{Ca}^{+2}$ antagonist nimodipine decreases and the $\mathrm{Ca}^{+2}$ agonist BAY K 8644 increases catecholamine synthesis in normal brain. Neuropharmacology $1987 ; 26$ : 101-5. 
14 Pileblad E, Carlsson A. In vivo effects of the $\mathrm{Ca}^{+2}$ antagonist nimodipine on dopamine metabolism in mouse brain. J Neural Transm 1986; 66: 171-87.

15 Perney TM, Hirning LD, Leeman SE, Miller RL. Multiple calcuim channels mediate neurotransmitter release from peripheral neurons. Roc Nad Acad Sci USA 1986; 83: 6656-9.

16 Barffai $T$, Vizi SE. Prevention by nimodipine, a calcium entry blocker, of the effect of $\alpha_{2}$-adrenoreceptor blocking agents on noradrenaline release: differential effects of nimodipine on $\left[{ }^{3} \mathrm{H}\right]$ noradrenaline and $\left[{ }^{14} \mathrm{C}\right]$ acetylcholine release measured concomitantly from the guinea pig ileum. Arch Int Pharmacodyn Ther 1986; 284: 212-24.

17 Costa G. Saija A, Padovano I, Trimarchi GR, DePasquale $R$, Caputi $A P$. The calcium antagonist nimodipine increases $\boldsymbol{\beta}$-endorphin release from rat hypophysis through an action on adrenal glands: an "in vivo" and "in vitro" study. Pharmacol Res Commun 1984; 16: 959-68.

18 Brandt L, Ljunggren B, Säveland H, Andersson K-E. Use of a calcium antagonist in aneurysmal subarachnoid haemorrhage. In: Danhoutte PM, Paoletti R, Govoni S (Eds.). Calcium Antagonists: Pharmacology and Clinical Research (Annals New York Academy of Sciences, Vol. 522), New York: New York Academy of Sciences, 1988: 667-75. 